\title{
PROJEKT GAZOCIĄGU TURKISH STREAM - IMPLIKACJE DLA WSPÓŁPRACY ROSJI I TURCJI
}

\author{
Justyna Misiągiewicz \\ Uniwersytet Marii Curie-Skłodowskiej w Lublinie \\ Wydział Politologii \\ ORCID ID: 0000-0003-0224-2735 \\ e-mail: justyna.misiagiewicz@poczta.umcs.lublin.pl
}

\begin{abstract}
Streszczenie: Przedmiotem analizy artykułu jest budowa Turkish Stream, gazociągu eksportowego z Rosji, który będzie docierał na rynek energetyczny Turcji, a następnie ma przekroczyć granicę tego państwa z Grecją i kierować się do Europy Południowej. Działania Federacji Rosyjskiej demonstrują chęć odzyskania strategicznej pozycji w relacjach z Turcją i państwami Europy Południowej kosztem Unii Europejskiej. Propozycje Rosji są zgodne z polityką Turcji, która dąży do wzmocnienia swojej roli w regionie. Wspólny strategiczny projekt energetyczny połączy znacząco interesy Rosji i Turcji pomimo wielu sprzeczności oraz zwiększy znaczenie tych państw nie tylko w wymiarze energetycznym, lecz także geostrategicznym.
\end{abstract}

Słowa kluczowe: Turkish Stream, polityka bezpieczeństwa energetycznego, współzależności energetyczne Rosji i Turcji

\section{WPROWADZENIE}

Problemem badawczym niniejszego opracowania jest projekt infrastruktury przesyłowej gazu do Europy - Turkish Stream ${ }^{1}$. W tym kontekście kluczową rolę odgrywa Rosja, jako główny światowy eksporter paliw kopalnych. Priorytetem strategii energetycznej tego państwa jest rozwój infrastruktury transportowej oraz wywieranie większego wpływu na cenę surowców. Federacja Rosyjska traktuje swój potencjał energetyczny jako instrument polityki zagranicznej oraz dąży do odgrywania roli monopolisty, jeśli chodzi o dostawy węglowodorów na rynki zachodnie.

Rosja obecnie finalizuje budowę gazociągu Turkish Stream, którym ma być dostarczany gaz do Turcji z pominięciem Ukrainy. Jest to projekt gazociągu eks-

\footnotetext{
1 Kwestia ta została poruszona w: [Misiągiewicz 2019].
} 
portowego, który stanowi odzwierciedlenie jednego z najbardziej strategicznych celów polityki energetycznej Rosji w czasach Władimira Putina, czyli zmniejszenie, a w rezultacie - wyeliminowanie zależności tranzytowej od państw poradzieckich. Działania Federacji Rosyjskiej demonstrują chęć odzyskania strategicznej pozycji w relacjach z Turcją oraz spotykają się z pozytywnym odzewem ze strony Turcji, która dąży do wzmocnienia swojej roli w regionie.

W niniejszym opracowaniu próbowano odpowiedzieć na następujące pytanie badawcze: w jaki sposób projekt infrastruktury gazociągowej Turkish Stream wpływa na współpracę energetyczną między Rosją i Turcją? W pracy zweryfikowano następujące hipotezy badawcze:

1. Rosja dąży do odgrywania roli monopolisty, jako dostawca surowców energetycznych na rynki zachodnie, czego potwierdzeniem jest koncentrowanie się na realizacji projektu gazociągu Turkish Stream.

2. Współpraca między Rosją i Turcją w wymiarze energetycznym będzie postępować z uwagi na zbieżność interesów obu państw.

Podejściem teoretycznym niniejszego opracowania jest teoria współzależności. Współzależności w wymiarze polityki energetycznej warunkują bowiem dynamikę stosunków międzynarodowych. Wyznacznikiem międzynarodowych współzależności energetycznych jest polityka transportu surowców. Drogi przebiegu rurociągów są wytyczane, biorąc pod uwagę uwarunkowania gospodarcze, ale również stanowią efekt działań politycznych państw. Specyfika współzależności energetycznych w opisywanym obszarze badawczym wynika ze złożoności relacji między różnymi podmiotami zaangażowanymi w realizację projektu Turkish Stream.

W realizacji problemu badawczego zastosowana zostanie metoda czynnikowa, charakterystyczna dla nauki o polityce. Będzie ona przydatna w celu identyfikacji, klasyfikacji i hierarchizacji uwarunkowań wewnętrznych i zewnętrznych budowy infrastruktury gazociągowej Turkish Stream. Techniki badawcze, użyteczne w działaniach naukowych, to analiza literatury, dokumentów oraz danych statystycznych.

Tematyka współzależności w wymiarze polityki energetycznej Rosji i Turcji w kontekście realizacji projektu gazociągu Turkish Stream rzadko bywa przedmiotem analiz w literaturze przedmiotu w języku polskim.

\section{UWARUNKOWANIA PROJEKTU}

Rosja jest współcześnie jednym z głównych światowych eksporterów paliw kopalnych. W grudniu 2005 roku prezydent W. Putin podczas posiedzenia Rady Bezpieczeństwa Federacji Rosyjskiej określił Rosję mianem „energetycznego mocarstwa” [Wyciszkiewicz 2008]. Stwierdził on ponadto, iż „energetyka stanowi najważniejszą siłę napędową światowego rozwoju gospodarczego" [Wyciszkiewicz 2008: 7]. Elity rządzące w Rosji są przekonane, iż bogactwo w surowce 
energetyczne zapewni temu państwu dobrobyt i potężną pozycję na arenie międzynarodowej w dłuższym czasie [Bahgat 2010: 163].

Najważniejszą rolę w polityce bezpieczeństwa energetycznego Rosji odgrywają ogromne zasoby surowców energetycznych. Pod względem wielkości udokumentowanych złóż gazu ziemnego zajmuje pierwsze miejsce w skali globalnej [Fredholm 2011: 2; CIA the World...]. Państwo to posiada największe na świecie złoża gazu ziemnego ${ }^{2}$. Jednym z głównych priorytetów Rosji jest rozwój infrastruktury energetycznej oraz wywieranie większego wpływu na cenę surowców energetycznych przez dialog z państwami producentami i konsumentami [Ronek 2017; Młynarski 2011: 167; Bodio 2009: 79]. Celem Rosji jest ponadto wykorzystanie przewagi surowcowej i logistycznej na rynku europejskim oraz zapewnienie stałych i wysokich dochodów z dostaw węglowodorów na rynek europejski.

Strategicznym celem Federacji Rosyjskiej jest transport gazu tzw. szlakiem południowym przez Morze Czarne na rynek europejski, z pominięciem Cieśnin Bosfor i Dardanele. Początkowo forsowano projekt gazociągu South Stream (mapa 1), który został ogłoszony w czerwcu 2007 roku. Konsorcjum South Stream AG powstało już w styczniu 2008 roku [South Stream Pipeline]. 15 maja 2009 roku w Soczi szefowie Gazpromu oraz koncernów energetycznych serbskiego, bułgarskiego, greckiego i włoskiego podpisali porozumienia dotyczące realizacji projektu South Stream [South Stream - nowe... 2009]. Zgodnie z deklaracjami przedstawicieli Gazpromu i włoskiego Eni, gazociąg miał być znaczącym krokiem w kierunku zapewnienia bezpieczeństwa dostaw gazu dla całej Europy [South Stream Pipeline]. Uruchomienie infrastruktury przesyłowej było planowane na rok 2015. Gazociąg miał przebiegać z miejscowości Beregovaya nad Morzem Czarnym do portu Varna w Bułgarii $(900 \mathrm{~km})$, a następnie za pomocą rurociągów na północny zachód przez Serbię i Węgry do Austrii oraz na południowy zachód do Włoch przez terytorium Grecji i Albanii [South Stream Pipeline].

1 grudnia 2014 roku podczas wizyty w Turcji prezydent Władimir Putin oświadczył, że ze względu na „niekonstruktywne stanowisko Komisji Europejskiej oraz bierność władz Bułgarii Rosja jest zmuszona wstrzymać budowę gazociągu South Stream" [Kardaś 2014]. Również prezes koncernu Gazprom Aleksiej Miller uznał projekt za zamknięty. Jednocześnie Gazprom i koncern energetyczny Turcji BOTAS podpisały memorandum zapowiadające budowę nowego gazociągu przez Morze Czarne, umożliwiającego dostawy zarówno na rynek turecki, jak i do państw Europy Południowej.

2 Wielkość tych złóż szacuje się na ok. 45 bln $\mathrm{m}^{3}$ (na drugim miejscu jest Iran - 26,6 bln m³ na trzecim Katar - 25,8 bln $\mathrm{m}^{3}$, na czwartym Arabia Saudyjska - 6,5 bln $\mathrm{m}^{3}$ ). Do 2008 roku Rosja była największym producentem i eksporterem gazu ziemnego na świecie (w 2009 roku jego produkcja spadła tam do $527 \mathrm{mld} \mathrm{m}^{3}$, a w USA wyniosła $593 \mathrm{mld} \mathrm{m}^{3}$ ) [Ronek 2017; Młynarski 2011: 167; Bodio 2009: 79]. 


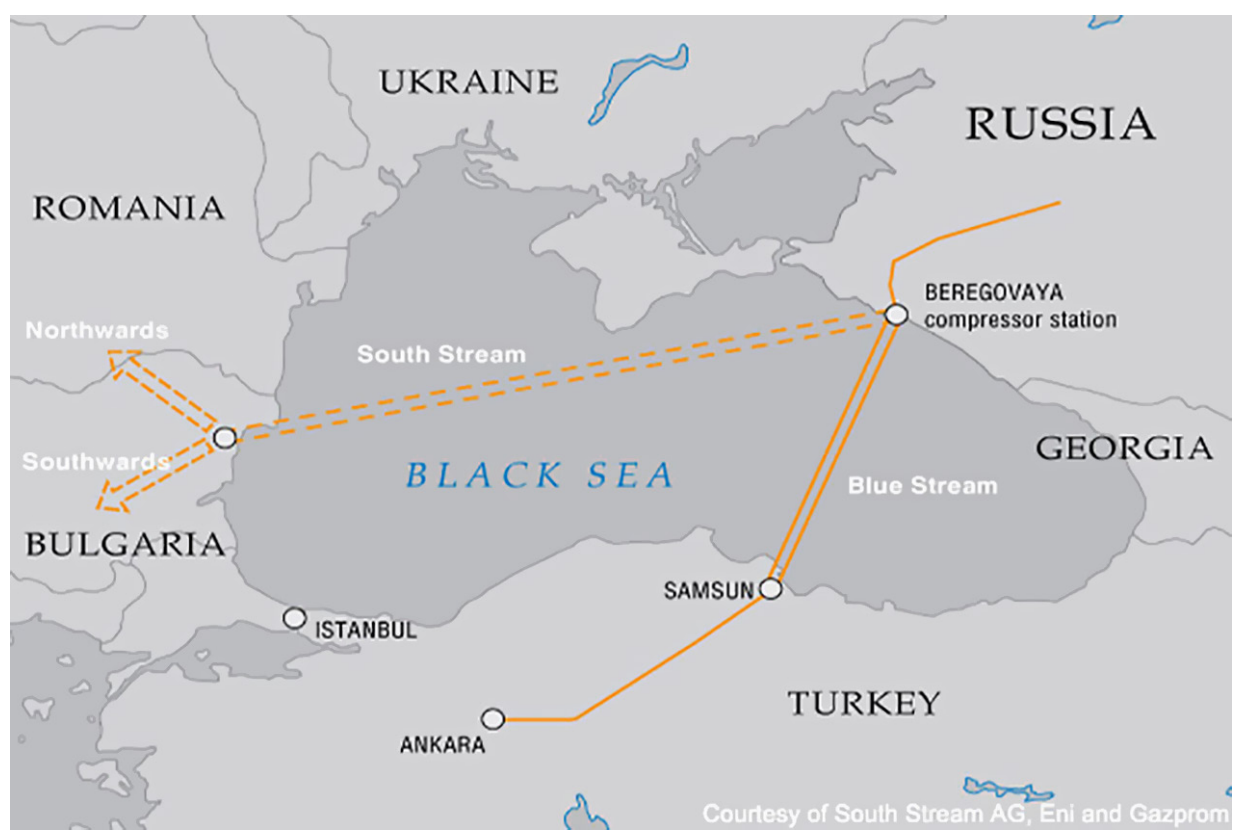

Mapa 1. Projekt gazociągu South Stream.

Źródło: South Stream Pipeline, [online], http://therearenosunglasses.files.wordpress.com/2008/11/1-southstream-pipeline.jpg [dostęp: 12.03.2011].

W sferze energetycznej konflikt na wschodzie Ukrainy doprowadził początkowo do załamania dialogu między Rosją a Unią Europejską. Tym samym całkowicie zahamowano prace nad szlakiem South Stream [Jarosiewicz 2015: 21]. Doprowadziło to również do przewartościowań w polityce energetycznej w regionie - zastąpienia przez Rosję projektu South Stream szlakiem Turkish Stream oraz powrotu Komisji Europejskiej do wspierania na poziomie dyplomatycznym i politycznym Południowego Korytarza Gazowego, widzianego jako szlak dostaw nie tylko z Azerbejdżanu, ale także z Turkmenistanu [Jarosiewicz 2015: 21].

Decyzja Rosji o odrzuceniu lobbowanego przez lata projektu South Stream i zastąpienie go pomysłem budowy gazociągu przez Morze Czarne i Turcję do granicy z Grecją - Turkish Stream, „wywróciły dotychczasowe założenia, na których opierała się polityka energetyczna w regionie" [Jarosiewicz 2015: 21]. Do tej pory istniało przekonanie między innymi w państwach UE, że Rosja jest zdeterminowana do budowy szlaku South Stream celem uzyskania dostępu do końcowego odbiorcy w UE. Tymczasem okazało się, że brak współdziałania ze strony UE może zastąpić współpracą z Turcją [Jarosiewicz 2015: 22].

Główną przyczyną decyzji Rosji o zaniechaniu budowy gazociągu South Stream były problemy finansowe Gazpromu wynikające m.in. z sankcji (koszty gazociągu zdrożały o blisko 40\%; objęte sankcjami firmy uczestniczące w budowie miały problemy z zaciąganiem kredytów inwestycyjnych) [Kardaś 2014]. Istotny wpływ miało także stanowisko Komisji Europejskiej, kwestionującej 
zgodność z prawem UE umów zawartych przez Rosję z państwami, przez które miał przechodzić rosyjski gazociąg, oraz stanowisko Bułgarii, która zawiesiła prace nad projektem.

Rezygnacja z South Stream stanowi niewątpliwie porażkę polityki energetycznej Rosji. Jednak zapowiedź możliwości budowy nowego gazociągu do Turcji jest nowym wyzwaniem dla bezpieczeństwa energetycznego w regionie. Rosja jest bowiem gotowa powrócić do projektu w podobnym kształcie [Kardaś 2014]. Ewentualna realizacja rosyjskich planów względem Turcji (budowa hubu gazowego) oznaczałaby ,przejęcie przez Rosję kontroli nad dostawami gazu z terytorium Turcji do UE i potencjalnie odcięcie jakichkolwiek przyszłych dostaw z Bliskiego Wschodu do UE. Niewykluczone, że Rosja wykorzysta również deklarację o rezygnacji z South Streamu do wzmocnienia narracji o gazowym zwrocie na Wschód"3 [Kardaś 2014].

Turcja jest z kolei chłonnym rynkiem zbytu dla surowców energetycznych, a jej położenie geograficzne umożliwia odgrywanie roli państwa tranzytowego, jeśli chodzi o transport surowców energetycznych na rynki europejskie. Tym samym jest ona istotnym partnerem gospodarczym dla państw posiadających ropę i gaz, jak i dla państw tych surowców pozbawionych [Penerliev 2012: 177]. Priorytet polityki gospodarczej Turcji stanowi zwiększenie aktywności w dziedzinie regionalnej polityki energetycznej [Efegil 2000: 58]. Trzy czwarte światowych zasobów ropy i gazu jest ulokowane w sąsiedztwie Turcji. Biorąc pod uwagę fakt geograficznego usytuowania, między producentami i konsumentami surowców energetycznych, Turcja nie tylko dąży do osiągnięcia statusu państwa tranzytowego dla ropy i gazu. Pragnie ona również odgrywać aktywną rolę w procesie ich redystrybucji. Tranzyt i sprzedaż nośników energii są dla Turcji znaczącym źródłem dochodów. Służą również wzmacnianiu jej pozycji w Europie i Azji [Misiągiewicz 2011]. Turcja oferuje najprostszą i najbezpieczniejszą drogę transportu surowców przez wschodnią część jej terytorium do Morza Śródziemnego i dalej na rynki europejskie. Staje się tym samym pożądanym partnerem i dla Rosji, i UE. Próbuje ona wygrywać na sprzecznościach między tymi podmiotami w celu maksymalizacji korzyści politycznych i finansowych ze współpracy z każdą ze stron [Jarosiewicz 2015: 30].

3 Ewentualne utworzenie przez Rosję hubu gazowego na granicy turecko-greckiej oznaczałoby podłączenie się jej do koncepcji Korytarza Południowego, co podważałoby sens realizacji projektu gazociągu transanatolińskiego - TANAP. Dawałoby to Rosji instrument umożliwiający przejmowanie kontroli nad przesyłem gazu przez Turcję, co potencjalnie mogłoby służyć blokowaniu innych projektów mających na celu dywersyfikację źródeł dostaw gazu do UE. 


\section{SPECYFIKA PROJEKTU}

Propozycja budowy gazociągu określonego mianem Turkish Stream (mapa 2) padła 1 grudnia 2014 roku podczas wizyty prezydenta Rosji Władimira Putina w Ankarze. Deklaracja o wznowieniu rozmów w sprawie budowy gazociągu z Rosji przez Morze Czarne do Turcji i dalej do Europy została ogłoszona 9 sierpnia 2016 roku w Petersburgu po spotkaniu prezydenta Turcji Recepa Tayyipa Erdoğana i prezydenta Rosji Władimira Putina. W 2016 roku Gazprom uzyskał wszelkie pozwolenia na budowę rurociągu od strony Turcji, zwłaszcza zgodę na przebieg infrastruktury przez wyłączną strefę ekonomiczną i wody terytorialne tego państwa [TurkStream]. Rury pierwotnie przeznaczone do realizacji South Stream zostały wykorzystane do budowy pierwszej nitki Turkish Stream.

W październiku 2016 roku w Stambule Rosja i Turcja podpisały porozumienie międzyrządowe dotyczące budowy gazociągu. W październiku 2018 roku Rosja i Turcja podpisały porozumienie międzyrządowe dotyczące budowy dwóch podwodnych nitek gazociągu Turkish Stream na Morzu Czarnym [Gazprom says Turkish... 2018]. Długość odcinka lądowego w Turcji ma wynosić około $180 \mathrm{~km}$. Pierwsza nitka Turkish Stream ma mieć przepustowość w wymiarze $15,75 \mathrm{mld} \mathrm{m}^{3}$, a jej możliwości przesyłowe na rynek europejski mają wynieść $31,5 \mathrm{mld} \mathrm{m}^{3}$ [Gazprom says Turkish... 2018].

W listopadzie 2018 roku zakończono budowę morskiego odcinka gazociągu Turkish Stream [Kardaś 2018]. 19 listopada 2018 roku prezydenci Recep Tayyip Erdoğan i Władimir Putin uczestniczyli w ceremonii otwarcia podmorskiej części gazociągu Turkish Stream. Długość rurociągu przebiegająca po dnie Morza Czarnego do wybrzeży Turcji wynosi $930 \mathrm{~km}$ [Oruc 2018]. W najgłębszym miejscu gazociąg jest usytuowany na głębokości $2200 \mathrm{~m}$ [TurkStream].

Trasa gazociągu nie została jednak ostatecznie sprecyzowana, według wstępnych informacji Turkish Stream ma przebiegać równolegle do projektowanej trasy South Stream i przed wejściem na wody terytorialne Bułgarii skręcać na południe w kierunku Turcji (mapa 2). Gazociąg Turkish Stream dociera na rynek Turcji niedaleko Kıyıköy do centrum dystrybucji gazu w Lüleburgaz, a następnie ma przekroczyć granicę Turcji z Grecją w miejscowości İpsala [TurkStream]. Deklarowana przepustowość obu nitek gazociągu ma wynieść $63 \mathrm{mld} \mathrm{m}^{3}$ (tyle samo co wcześniejszy projekt South Stream).

W ramach Turkish Stream Rosja zaproponowała także utworzenie hubu gazowego na terytorium Turcji, nie precyzując jednak, na czym miałby on polegać (poza ogólną informacją, że miałoby do niego trafiać ok. 47-49 $\mathrm{mld} \mathrm{m}^{3}$ gazu) [Jarosiewicz 2015: 22]. Prezydent Putin zasugerował w lutym 2015 roku możliwość przedłużenia Turkish Stream do Baumgarten [Jarosiewicz 2015: 22]. Kwestia finansowania gazociągu nie została ustalona. Nie sprecyzowano również, jakie firmy będą pełnić rolę podwykonawców (Rosja promuje Gazprom). Podmorski odcinek gazociągu ma układać firma Saipem [Jarosiewicz 2015: 23]. 


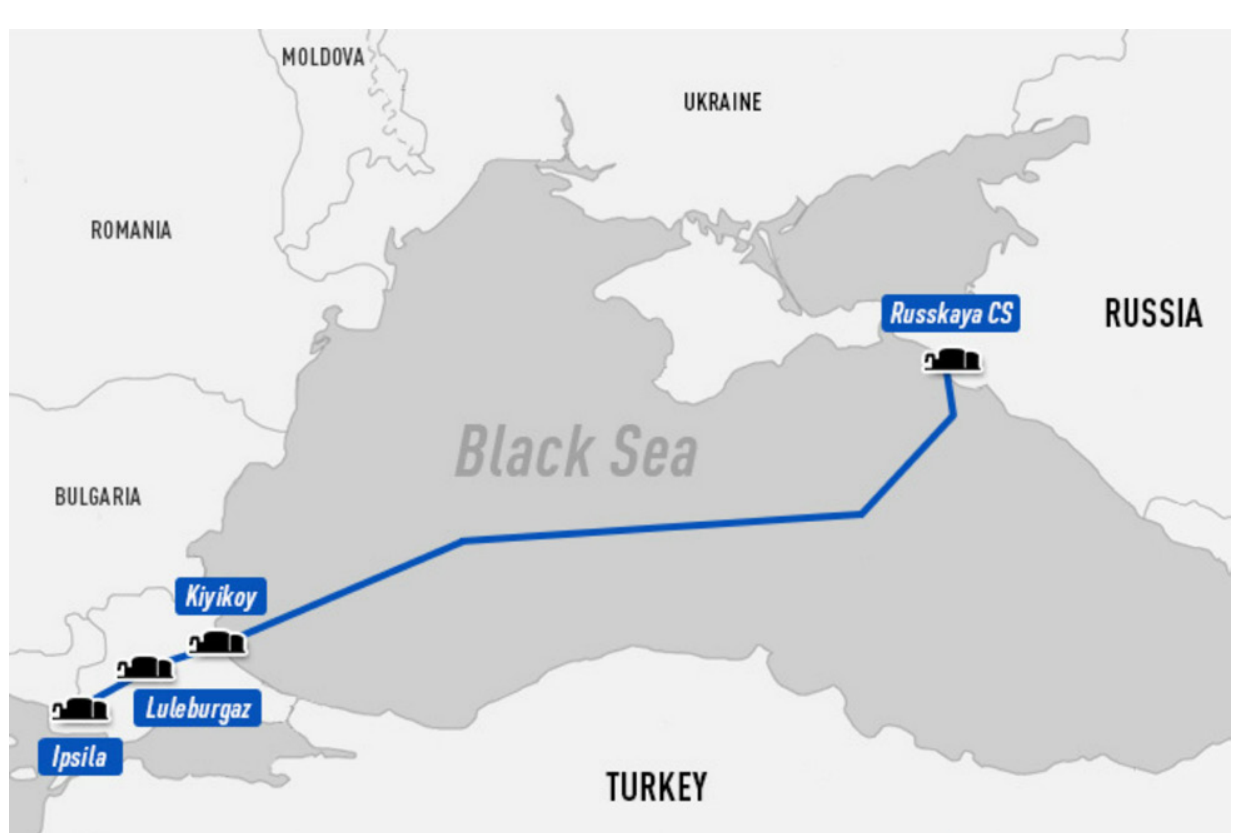

Mapa 2. Przebieg gazociągu Turkish Stream.

Źródło: https://www.euractiv.com/section/energy/news/speculation-rife-over-russia-s-turkish-stream-loan-togreece/ [dostęp: 01.03.2019].

Zgodnie z deklaracjami szefa Gazpromu, „Gazociąg Turkish Stream, mający na celu dostawy gazu z Rosji do Turcji w przyszłym (2019) roku przez Morze Czarne, jest ukończony w 80 procentach" [Gazprom says Turkish... 2018]. Minister Energetyki Rosji Alexander Novak zadeklarował, że cała infrastruktura zacznie przesyłać gaz już pod koniec 2019 roku [Kerimkhanov 2019]. Gazociąg będzie dostarczał surowiec na rynek europejski za pośrednictwem Bułgarii, Serbii lub Grecji i Włoch w 2019 roku [Gazprom says Turkish... 2018]. Gazprom na oficjalnym koncie Instagramu zadeklarował, iż dziennie budowane jest $6,27 \mathrm{~km}$ rur gazociągu [Gazprom says Turkish... 2018]. Projekt ten pozwala na realizację celów rosyjskiej polityki zagranicznej, ale mimo ambitnych deklaracji ze strony Rosji i Gazpromu, nadal nie wiadomo, jak i kiedy Gazprom dostarczy gaz przez Turcję na południe Europy.

Turkish Stream to kolejny gazociąg eksportowy, który będzie przebiegał szlakiem omijającym Ukrainę. Oznacza to realizację jednego z najbardziej strategicznych celów polityki energetycznej Rosji, czyli wyeliminowanie zależności tranzytowej od tego państwa. Budowa Turkish Stream przybliża Rosję do tego celu [Kardaś 2018]. Pomysł realizacji nowego gazociągu na południu Europy umożliwi również rozbudowę infrastruktury rurociągowej na terytorium Federacji Rosyjskiej. Realizacja tego projektu przyczyniła się tym samym do zwiększenia „poziomu gazyfikacji państwa” [Kardaś 2018]. Turkish Stream zwiększa również „poziom elastyczności Gazpromu, jeżeli chodzi o politykę handlową prowadzoną wobec odbiorców europejskich" [Kardaś 2018]. 
Po dnie Morza Czarnego mają przebiegać dwie nitki Turkish Stream - jedna z nich ma być przeznaczona na potrzeby rynku Turcji. Natomiast według zapowiedzi Gazpromu drugą gaz miałby być dostarczany do odbiorców w Europie Południowej [Kardaś 2018; Gazprom says Turkish ... 2018]. Druga nitka Turkish Stream będzie przeznaczona dla Bułgarii, Rumunii, Serbii czy Węgier lub ewentualnie będzie stanowić pewne rezerwy na wypadek, gdyby popyt się zwiększył.

\section{WSPÓŁZALEŻNOŚCI ROSJI I TURCJI}

Działania Rosji demonstrują chęć odzyskania przez nią strategicznej pozycji w relacjach z Turcją i państwami Europy Południowej kosztem UE. Propozycje Rosji spotykają się z zainteresowaniem ze strony Turcji, która dąży do wzmocnienia swojej pozycji w regionie. Dążenia Turcji są spójne z oczekiwaniami Rosji, która liczy na zacieśnienie współpracy, proponując jej wspólne kształtowanie szlaków energetycznych do UE. Rosja zmniejsza również swoją zależność tranzytową od Ukrainy, ale w przypadku uruchomienia dostaw drugą nitką Turkish Stream w kwestiach tranzytu stanie się ona zależna od Turcji, która nie jest łatwym partnerem negocjacyjnym. Nie jest jasne, jakie będą warunki eksploatacji infrastruktury lądowej, która będzie wykorzystywana do tranzytu [Kardaś 2018]. Rosja liczy na to, że w przypadku niemożności dostarczenia przez Azerbejdżan odpowiednich wolumenów gazu infrastrukturą Południowego Korytarza Gazowego mógłby nim również popłynąć gaz rosyjski [Kardaś 2018]. Pod względem politycznym i ekonomicznym uruchomienie nawet tylko jednej nitki Turkish Stream stanowi negatywne konsekwencje dla Ukrainy. W przypadku uruchomienia i pełnego wykorzystania obu nitek gazociągu wolumen tranzytu rosyjskiego gazu przez Ukrainę zmniejszy się o blisko jedną trzecią [Kardaś 2018].

Tym samym pojawiły się dwa konkurencyjne projekty infrastruktury gazociągowej w regionie: Turkish Stream oraz gazociągu z Azerbejdżanu przez Turcję do UE [Gurbanov 2017]. Oba projekty przebiegają przez terytorium Turcji i zakładają, że punktem wejścia na rynek UE będzie granica Turcji z Grecją lub Turcji z Bułgarią [Jarosiewicz 2015: 22]. Można wnioskować, iż Turcja gra na „dwa fronty" w wymiarze dostaw i tranzytu gazu przez swoje terytorium. Tym samym Azerbejdżan nie uniknie rywalizacji z rosyjskim gazem na rynku europejskim, mimo że ma podpisane umowy z odbiorcami w UE, obawia się, że poprzez Turkish Stream Rosja zechce utrzymać swoją dominację na rynku greckim i bułgarskim i nie dopuści tam gazu azerbejdżańskiego.

Rosyjska propozycja została skierowana do Turcji, co wzmocniło jej pozycję wobec Azerbejdżanu i UE. W takiej sytuacji Turcja zachowuje się jak główny rozgrywający kwestii gazowych w regionie, dostrzegając determinację Moskwy do realizacji Turkish Stream, negocjuje obniżkę cen gazu [Jarosiewicz 2015: 24]. Propozycja Rosji niewątpliwie wpływa na kalkulacje energetyczne Turcji, bo zwiększa szansę na przekształcenie jej w centrum redystrybucji handlu gazem, 
a także podnosi jej polityczne znaczenie [Jarosiewicz 2015: 25]. Pomysł budowy Turkish Stream wpływa również na kalkulacje państw Unii, które są potencjalnymi odbiorcami azerskiego gazu z Korytarza Południowego. Dotyczy to przede wszystkim Grecji, której Rosja zaproponowała uczestnictwo w projekcie Turkish Stream.

Każdy z wariantów dostaw do UE jest sprzeczny z interesami Rosji, która stara się zachować dominującą pozycję dostawcy gazu na rynek unijny i nie jest zainteresowana konkurencją z azerbejdżańskim gazem. Rosja po upadku projektu Nabucco ${ }^{4}$ nie odnosiła się do kwestii dostaw azerbejdżańskiego gazu do Europy.

\section{PERSPEKTYWY REALIZACJI}

Turkish Stream stanowi ogromne wyzwanie dla rynku energetycznego w Europie, i odwrotnie, rynek energetyczny to wyzwanie dla realizacji projektu gazociągu. Ceny ropy, sankcje ekonomiczne dla przedsiębiorstw z Rosji czy koszty projektu mogą skomplikować lub nawet ograniczyć sfinansowanie tak ambitnego przedsięwzięcia energetycznego. Nie należy również zapominać kosztów finansowych, jakie poniósł Gazprom po porażce projektu South Stream. Musiał on zapłacić rekompensaty w wysokości miliarda dolarów korporacjom: ENI, German Wintershall, Electricite de France, za ich członkostwo w konsorcjum [Gurbanov 2017]. Rosja ponadto wynajęła dwa okręty w celu budowy rurociągu South Stream od włoskiej firmy Saipem, a po zawieszeniu projektu w 2014 roku Gazprom musiał płacić tej firmie 25 mln dolarów miesięcznie [Gurbanov 2017]. W czerwcu 2015 roku Gazprom zerwał kontrakt z firmą Saipem, zaangażowaną w budowę morskiej części gazociągu Turkish Stream, ponosząc z tym związane wysokie koszty.

Zgodnie z raportem Ministerstwa Rozwoju Gospodarczego Rosji oraz banku Sberbank, produkcja gazu w tym państwie zmniejszyła się w roku 2015 w porównaniu z rokiem poprzednim. Również doszło w tym okresie do zmniejszenia dochodów z eksportu gazu, zgodnie z deklaracjami Federal Customs Service Rosji [Gurbanov 2017]. Raport Sberbank wskazuje na redukcję dochodu Gazpromu w tym kontekście. Koszt budowy gazociągu Turkish Stream może wynieść 11,4 mld dolarów [Gurbanov 2017]. Pierwsza linia gazociągu to koszt rzędu 5-6 mld dolarów, jednak koszty te mogą wzrosnąć w związku z fluktuacją cen ropy. Oprócz tego Rosja nie będzie mogła upolitycznić Turkish Stream i tym samym wywierać wpływu na Turcję, tak jak to się działo w przypadku Ukrainy. Dodatkowo polityka dywersyfikacji źródeł dostaw energii oraz sankcje gospodarcze UE skierowane wobec Rosji mogą skomplikować realizację projektu.

4 Gazociąg Nabucco, którym miał popłynąć do państw Unii Europejskiej gaz z Azji Centralnej i Bliskiego Wschodu za pośrednictwem Turcji. Projekt zakładał budowę gazociągu o długości 3300 km przez Turcję, Bułgarię, Rumunię i Węgry do Austrii, którym popłynąłby gaz z Azerbejdżanu, Egiptu, Iraku i Turkmenistanu. 
Adresując projekt Turkish Stream do państw uczestniczących w projektach Południowego Korytarza Gazowego, Rosja zyskuje narzędzie do utrudniania ich realizacji. Tym samym UE traktuje Turkish Stream jako projekt „zagrażający realizacji Południowego Korytarza Gazowego" [Gurbanov 2017]. Komisarz ds. Unii Energetycznej Maroš Šefčovič otwarcie krytykował powstanie gazociągu Turkish Stream, argumentując, iż „decyzja dotycząca budowy rurociągu powinna być podjęta zgodnie ze strategią bezpieczeństwa energetycznego UE" [Gurbanov 2017]. Również Komisarz ds. Konkurencji Margaret Vestager podała w wątpliwość umowy Gazpromu z państwami UE dotyczące budowy gazociągu, z uwagi na sprzeczność z prawem Unii [Gurbanov 2017]. Zadeklarowała ona, iż „każda firma działająca na rynku UE, niezależnie od państwa pochodzenia, musi funkcjonować zgodnie z prawem Unii” [za: Gurbanov 2017]. Paradoksalnie w tę retorykę wtapia się deklaracja prezydenta Rosji, który stwierdził w styczniu 2019 roku, iż „oczywiście, stanowisko Komisji Europejskiej będzie brane pod uwagę w procesie podejmowania ostatecznej decyzji dotyczącej trasy dostaw gazu z Rosji [...] wierzymy, iż państwa UE, zainteresowane importem rosyjskiego gazu, uzyskają gwarancje UE, iż plany przedłużenia gazociągu Turkish Stream, nie będą zakłócone arbitralnymi, politycznymi decyzjami Brukseli” [Putin advises EU...].

Gazociąg Turkish Stream spotkał się z ostrą krytyką Stanów Zjednoczonych Ameryki. W maju 2015 roku Amos Hochstein z Departamentu Stanu USA podczas wizyty w Atenach naciskał na Grecję, by poparła budowę gazociągu łączącego złoża w Azerbejdżanie z rynkiem europejskim (Korytarz Południowy), który zredukuje uzależnienie UE od importu gazu z Rosji, a nie gazociągu Turkish Stream, który stanowi realizację interesów Rosji [Gurbanov 2017]. Hochstein stwierdził, iż „nie jest to projekt o znaczeniu ekonomicznym, ale stricte politycznym" [Gurbanov 2017]. Sekretarz ds. Energii USA Rick Perry również zwrócił się do państw Europy Środkowej i Wschodniej o odrzucenie projektu infrastruktury rosyjskiej [Gotev 2018]. Podczas wizyty w Budapeszcie w listopadzie 2018 roku stwierdził on, iż: „Dywersyfikacja dostaw energii jest najważniejsza dla regionu, zwłaszcza że Rosja wielokrotnie używała energii, jako broni [...] Rosja wykorzystuje infrastrukturę Nord Stream 2 i Turkish Stream, by umocnić kontrolę nad bezpieczeństwem i stabilnością w regionie Europy Środkowej i Wschodniej” [za: Gotev 2018].

Można więc śmiało stwierdzić, iż projekt infrastruktury Turkish Stream stanowi element polityki energetycznej Federacji Rosyjskiej, polegającej na zacieśnianiu współpracy z państwami europejskimi, zwiększaniu wpływów na rynku energetycznym UE oraz eliminowaniu projektów ,alternatywnych”, które omijają Rosję. W takiej sytuacji realizacja gazociągu stoi w sprzeczności z podstawowymi założeniami polityki bezpieczeństwa energetycznego Unii, której głównym elementem jest dywersyfikacja źródeł dostaw węglowodorów. 


\title{
KONKLUZJE
}

Jeśli projekt Turkish Stream zostanie zrealizowany, Turcja stanie się bardzo znaczącym graczem na międzynarodowym rynku energetycznym. Wspólny strategiczny projekt energetyczny połączy znacząco interesy Rosji i Turcji pomimo wielu sprzeczności. Oba państwa mają ambiwalentny stosunek do polityki UE. Rosja w związku z sankcjami ekonomicznymi, a Turcja z powodu jej lekceważenia w procesie integracji ze strukturami UE oraz ostracyzmu ze strony państw europejskich wobec aspiracji autorytarnych prezydenta Erdoğana. Rosja ponadto chce zademonstrować, że nie jest państwem izolowanym na arenie międzynarodowej. Zdaje sobie bowiem sprawę z tego, że po zawieszeniu dostaw gazu za pośrednictwem Ukrainy dotychczasowi konsumenci nie będą mieć innej możliwości, jak sprowadzać gaz rurociągiem Turkish Stream [Gotev 2018]. Jednak dopóki gazociąg nie zostanie uruchomiony, Ukraina nadal może stanowić główne państwo tranzytowe dla gazu z Rosji do Europy, zwłaszcza że posiada do tego adekwatną infrastrukturę.

Title: The Turkish Stream Gas Pipeline Project - Implications for Cooperation between Russia and Turkey

\begin{abstract}
In this analysis, the Turkish Stream pipeline project infrastructure will be presented. We will concentrate on the gas transportation route from Russia to the Turkish energy market and then to the Southern European states. The Russian Federation, as the main exporter of the energy resources in the global scale, is interested to restore its strategic position in its relations with Turkey and the Southern European states. Such policy is corresponding with Turkish aspirations, to be much more influential in the region. Therefore, the joint strategic energy project will combine the interests of Russia and Turkey and will be important for both countries in terms of strengthening their position not only in the energy market, but also in the geostrategic dimension.
\end{abstract}

Keywords: Turkish Stream, energy security Policy, Russia - Turkey energy interdependences

\section{BIBLIOGRAFIA}

1. Bahgat G. (2010), Russia's oil and gas policy, „OPEC Energy Review”, s. 163. DOI: https:// doi.org/10.1111/j.1753-0237.2010.00178.x.

2. Bezpieczeństwo energetyczne we wspótczesnych stosunkach międzynarodowych. Wyzwania, zagrożenia, perspektywy. Energy security in the contemporary international relations. Challenges, threats, perspectives, (2017), red. M. Pietraś, J. Misiągiewicz, Wyd. UMCS, Lublin.

3. Bodio M. (2009), Polityka energetyczna w stosunkach między Unia Europejska a Federacja Rosyjska w latach 2000-2008, Wyd. Aspra, Warszawa, s. 79.

4. CIA The World Factbook, Russia, Oil, natural gas - proved reserves, [online], https://www.cia. gov/library/publications/the-world-factbook/geos/rs.html [dostęp: 12.09.2011].

5. Efegil E. (2000), In the 21st Century New World Order and Turkey, [w:] Turkey in the 21st Century: Changing Role In World Politics?, red. M. Tahiroglu, T.Y. Ismael, Ashgate, Famagusta, s. 58. 
6. Fredholm M. (2011), Globalization and Eurasia's energy sector, "The Journal of Central Asian Studies", vol. 20, s. 2.

7. Gazprom says Turkish Stream pipeline project 80 percent complete, (2018), "Daily Sabah" 30 sierpnia.

8. Gotev G. (2018), US warns Hungary and neighbors against Turkish Stream, [online], https:// www.euractiv.com/section/global-europe/news/us-warns-hungary-and-neighbors-against-turkish-stream/ 14 listopada [dostęp: 13.09.2018].

9. Gurbanov I. (2017), Perspective for 'Turkish Stream' Project: Possible Scenarios and Challenges, Jan 21, [online], https://www.naturalgasworld.com/perspective-for-turkish-stream-project-possible-scenarios-and-challenges-35401 [dostęp: 13.09.2011].

10. Jarosiewicz A. (2015), Poludniowy Korytarz Gazowy. Azersko-turecki projekt w rozgrywce Rosji i UE, „Punkt Widzenia”, nr 54, s. 21.

11. Kardaś S. (2014), Niechciany gazociag: Rosja wstrzymuje budowę South Streamu, „Analizy OSW" 12.03.

12. Kardaś S. (2018), Turkish Stream dla Europy pod znakiem zapytania (ROZMOWA), 26 listopada, [online], https://biznesalert.pl/turkish-stream-odnoga-europejska-2/ [dostęp: 13.09.2018].

13. Kerimkhanov A. (2019), Turkish Stream, „Azernews” 6.01.

14. Misiągiewicz J. (2019), Bezpieczeństwo energetyczne Unii Europejskiej. Implikacje nowych projektów infrastruktury gazociagowej w Europie, Wyd. UMCS, Lublin.

15. Misiągiewicz J. (2011), Działania Turcji wobec państw Azji Centralnej. Implikacje dla Unii Europejskiej, [w:] Turcja i Europa-wyzwania i szanse, red. A. Szymański, Wyd. Polski Instytut Spraw Międzynarodowych, Warszawa.

16. Młynarski T. (2011), Bezpieczeństwo energetyczne w pierwszej dekadzie XXI wieku. Mozaika interesów i geostrategii, Wyd. UJ, Kraków, s. 167.

17. Oruc M.Ş. (2018), All eyes are on the Turkish Stream pipeline, "Daily Sabah" 29.11.

18. Penerliev M. (2012), Asian "Energy Players" and Their Role in the Balkan Energy Strategy, "Journal of Settlements and Spatial Planning", vol. 3, nr 2, s. 177.

19. Putin advises EU nations to Get Brussel's guarantees of non-interferencje into Turk Stream, [online], https://tass.com/economy/1040153 [dostęp: 12.09.2020].

20. South Stream - nowe porozumienia, stare watpliwości, (2009), „Best OSW”, nr 19, s. 4. Ośrodek Studiów Wschodnich, [online], http://www.osw.waw.pl/pl/publikacje/best/2009-05-20/ numer-1994 [dostęp: 12.09.2010].

21. South Stream Pipeline, [online], http://www.hydrocarbons-technology.com/projects/southstream/ (01.04.2014).

22. TurkStream, [online], http://www.gazpromexport.ru/en/projects/ [dostęp: 13.09. 2018].

23. Wyciszkiewicz E. (2008), Rosyjski sektor naftowo-gazowy - uwarunkowania wewnętrzne i perspektywy rozwoju, [w:] Geopolityka Rurociagów. Wspólzależność energetyczna a stosunki międzypaństwowe na obszarze postsowieckim, red. E. Wyciszkiewicz, Wyd. Polski Instytut Spraw Międzynarodowych, Warszawa, s. 7. 